\title{
PENGARUH DIMENSI KEADILAN PAJAK DAN TAX MORALE TERHADAP TINGKAT KEPATUHAN WAJIB PAJAK BADAN YANG TERDAFTAR DI KPP PRATAMA KOTA BANDUNG
}

\author{
Dedy Suryadi \\ Jurusan Akuntansi Politeknik TEDC Bandung \\ E-mail: akuntansi@poltektedc.ac.id
}

\begin{abstract}
This study aimed to examine the effect of taxes and tax fairness dimensions of morale on the level of compliance with corporate taxpayers registered in KPP Bandung. Richardson (2006) and Azmi Perumal (2008) explains that there are five dimensions that influence tax compliance behavior, namely: (1) natural justice, (2) reciprocal government, (3) interest, (4) special provisions, (5) tax rate structure. While Mustikasari (2007) that (1) violates ethics, (2) guilt, (3) the principles of living a positive effect on tax compliance behavior.The study was conducted with a questionnaire survey method to test the primary data obtained from 72 respondents, using partial least squares analysis (PLS) was used to identify the dimensions of tax fairness and tax morale on tax compliance level agency listed in KPP Bandung. The results showed that the direct dimension tax fairness and tax morale significantly affect tax compliance Corporate Taxpayers are registered in KPP Bandung against the Taxpayer compliance rate, in which dimensions of tax justice has a positive effect on the level of compliance of Corporate Taxpayers and tax nor positive effect on the morale of the Taxpayer compliance rate.
\end{abstract}

Key words: taxes, tax fairness dimensions, tax morale, tax compliance.

\section{Pendahuluan}

Langkah pemerintah untuk meningkatkan penerimaan dari sektor perpajakan dimulai dengan melakukan reformasi perpajakan secara menyeluruh pada tahun 1983, dan sejak saat itulah, Indonesia menganut sistem self assesment. Penerapan self assesment system akan efektif apabila kondisi kepatuhan sukarela (voluntary compliance) pada masyarakat telah terbentuk (Damayanti, 2004). Kenyataan yang ada di Indonesia menunjukkan tingkat kepatuhan masih rendah, hal ini bisa dilihat dari belum optimalnya penerimaan pajak yang tercermin dari tax gap dan tax ratio. Data yang akurat mengenai berapa jumlah tax gap Indonesia belum tersedia. Namun dalam pidato pengukuhannya sebagai guru besar Fakultas Ekonomi Universitas Indonesia, Gunadi mengutip hasil laporan Badan Pemeriksa Keuangan dan Pembangunan (BPKP) tentang audit kinerja Direktorat Jenderal Pajak, bahwa Indonesia mengalami tax gap yang cukup signifikan. Dari sisi lain, tax ratio Indonesia paling rendah di kawasan ASEAN yaitu hanya rata-rata sebesar $12,2-13,5 \%$ untuk tahun 2001 - 2006 (Berita Pajak, 1 September 2005). Sementara itu tax ratio negara-negara ASEAN sebesar: Malaysia (20,17\%), Singapura (21,40\%), Brunai $(18,80 \%)$, dan Thailand (17,28\%). Angka tax gap yang signifikan dan tax ratio yang masih rendah ini menunjukkan usaha memungut pajak (tax effort) Indonesia masih rendah (Gunadi, 2004).

Jika tax ratio diukur dari Penerimaan Pajak Pusat saja terhadap PDB, maka tax ratioIndonesia untuk tahun 2006 adalah sebesar 12,16\%, tahun 2007 sebesar 12,43\%, tahun 2008 sebesar 13,31\%, tahun 2009 sebesar 11,06\%, tahun 2010 sebesar 11,26\%, dan untuk tahun 2011 lalu adalah sebesar 11,76\%. Kemudian jika alternatif kedua yang dipakai, yaitu jika tax ratio diukur dari (Penerimaan Pajak Pusat + Pajak Daerah) terhadap PDB, maka tax ratio 
Indonesia untuk tahun 2006 adalah sebesar 13,02\%, tahun 2007 sebesar 13,06\%, tahun 2008 sebesar 14,06\%, tahun 2009 sebesar $11,83 \%$, tahun 2010 sebesar 12,00\%, dan tahun 2011 lalu adalah sebesar $12,59 \%$. Sedangkan jika alternatif ketiga yang dipakai, yaitu jika tax ratio diukur dari (Penerimaan Pajak Pusat + Pajak Daerah + penerimaan dari SDA) terhadap PDB, maka tax ratio Indonesia untuk tahun 2006 adalah sebesar $18 \%$, tahun 2007 sebesar $16,43 \%$, tahun 2008 sebesar 18,59\%, tahun 2009 sebesar $14,31 \%$, tahun 2010 sebesar $14,64 \%$, dan tahun 2011 lalu adalah sebesar 15,48\%, jelaslah bahwa jika alternatif ketiga tax ratio yang dipakai, maka tax ratio Indonesia tidak kalah dengan rata-rata tax ratio negara-negara di kawasan ASEAN yang berkisar sekitar 15-17 persen itu. Kalau untuk rata-rata tax ratio kawasan Asia sendiri adalah sekitar 17-21 persen, sedangkan untuk rata-rata tax ratio negara-negara maju (seperti Jerman, Austria, Belgia, Denmark, Finlandia, Islandia, Perancis, Italia, Norwegia, Swedia) adalah 40 persen ke atas. (website:indodigest.com, Berita Pajak, Wiyoso Hadi, Pegawai Direktorat Jenderal Pajak, Selasa, 8 Mei 2012 - 14:01)

Sedangkan tingkat kepatuhan Wajib Pajak di Jawa Barat di nilai masih rendah, tidak hanya dalam pembayaran tapi juga pengembalian Surat Pemberitahuan Tahunan (SPT). Dari sekitar 1,3 juta Wajib Pajak di Jawa Barat pada 2011, hanya $40 \%$ masuk kategori pembayar aktif dan sekitar 26\% Wajib Pajak Badan (Perusahaan) dan 14\% Wajib Pajak Perorangan. (website: bisnisjabar; kabar ekonomi jabar, 25 Februari 2012).

Untuk mencapai target pajak, perlu ditumbuhkan terus menerus kesadaran dan kepatuhan masyarakat Wajib Pajak untuk memenuhi kewajiban pajak sesuai dengan ketentuan yang berlaku. Mengingat kesadaran dan kepatuhan Wajib Pajak merupakan faktor penting bagi peningkatan penerimaan pajak, maka perlu secara intensif dikaji tentang faktor-faktor yang memengaruhi kepatuhan Wajib Pajak, khususnya Wajib Pajak Badan.

Salah satu hal yang harus diperhatikan dalam penerapan pajak suatu negara adalah adanya keadilan, karena secara psikologis masyarakat menganggap bahwa pajak merupakan suatu beban dan masyarakat memerlukan suatu kepastian bahwa mereka mendapatkan perlakuan yang adil dalam pengenaan dan pemungutan pajak oleh negara, agar tidak menghambat jalannya sistem perpajakan yang ada, dikarenakan sistem pemungutan pajak di Indonesia menggunakan self assesment system. Prinsip keadilan ini sangat diperlukan agar tidak menimbulkan perlawananperlawanan pajak seperti tax avoidance maupun tax evasion.

Menurut Vogel, Spicer, dan Becker (dalam Richardson, 2006), pembayar pajak cenderung untuk menghindari membayar pajak jika mereka menganggap sistem pajak tidak adil, karena Wajib Pajak sering merasakan ketidak-adilan karena kurang merasakan manfaat yang mereka peroleh dari negara, misalnya jaminan keamanan penduduk sangat kurang karena terbatasnya sarana dan prasarana, infrastruktur yang tidak terpelihara, dan sebagainya.

Selain dimensi keadilan pajak, tax morale juga memiliki peranan dalam meningkatkan peningkatan pajak. Menurut Frey (dalam Simanjuntak dan Mukhlis, 2012) dalam teori moral pajak (tax morale theory) menyatakan motivasi intrinsik individu untuk bertindak, yang didasari oleh nilai-nilai yang dipengaruhi oleh norma-norma budaya. Menurut pendapat Frey (dalam Simanjuntak dan Mukhlis, 2012) bahwa tax morale dapat dipahami sebagai penjelasan prinsip-prinsip moral atau nilai-nilai yang diyakini seseorang membayar pajak, faktor yang mempengaruhi tax morale diantaranya (1) persepsi adanya kejujuran; (2) sikap membantu atau melayani dari aparat; (3) kepercayaan terhadap instansi pemerintah; (4) penghargaan atau rasa hormat dari aparat pajak (respect); (5) sejumlah sifat-sifat individu lainnya.

Disamping itu kepatuhan juga makin besar saat individu merasakan manfaat dari suatu barang publik yang didanai dari pembayaran pajaknya, sementara perubahan dalam tarif denda tampaknya memiliki pengaruh yang kecil atas perilaku kepatuhan pajak. Selain itu hasil estimasi juga mengindikasikan bahwa beberapa meskipun tidak semua kebijakan pemerintah dapat memiliki dampak yang signifikan pada kepatuhan.

\section{Tinjauan Literatur \\ 2.1. Keadilan Pajak}

Persepsi masyarakat mengenai keadilan sistem perpajakan yang berlakudi suatu negara sangat mempengaruhi pelaksanaan perpajakan yang baik di negaratersebut. Persepsi masyarakat ini akan mempengaruhi perilaku kepatuhan pajakdan perilaku penghindaran pajak (tax evasion). Masyarakat akan cenderung tidakpatuh dan menghindari kewajiban pajak jika merasa sistem pajak yang berlakutidak adil. Menurut Musgrave and Musgrave (dalam Simanjuntak, 2008) ukuran dalam menilai keadilan adalah benefit approach dan ability to pay approach. Ukuran benefit approach didasarkan pada manfaat 
dari jasa-jasa pemerintah yang diterima Wajib Pajak, dimana pembebanan pajak pada masingmasing Wajib Pajak didasarkan pada besarnya manfaat tersebut. Semakin besar manfaat yang diterima oleh Wajib Pajak, maka semakin besar beban pajaknya. Sedangkan ukuran ability to pay approach didasarkan pada kemampuan individu untuk membayar pajak, dimana kemampuan didasarkan pada tingkat kemakmuran yang diukur berdasarkan atas tingkat pendapatan, jumlah kekayaan, atau pengeluaran konsumsi individu. Semakin tinggi kemampuan individu untuk membayar pajak, maka beban pajak yang dibayar semakin besar.

\subsection{Tax Morale}

Tax morale akan berbeda-beda di setiap negara karena setiap negara memiliki kulturnya masingmasing. Teori ini dengan pendekatan psikologi masyarakat, berpandangan bahwa antara masyarakat dan pemerintah terdapat kontrak implisit yang mana masyarakat menyadari bahwa mereka memiliki hak dan kewajiban. Masyarakat dipandu tentang kebajikan warga negara (civic virtue), yaitu motivasi intrinsik pemenuhan kewajiban yang harus dihormati. Kebajikan warga negara diyakini akan muncul sebagai akibat hakhak partisipasi masyarakat secara kolektif dihormati. Perlakuan jujur aparat berwenang, misalnya akan direspon masyarakat secara positif, sistem pajak dan pelayanan administrasi pajak yang baik membuat masyarakat puas dan menjadi faktor pendorong wajib pajak meningkatkan kepatuhannya.

Erart dan Feinstein (1994) dalam tulisan teoritisnya menekankan pada relevansi dari mengintegrasikan sentiment moral ke dalam model untuk menghasilkan penjelasan yang cukup beralasan atas perilaku kepatuhan aktual. Lebih lanjut Andreoni, Erart, dan Feinstein (1998) (dalam Torgler, 2007), menekankan pada survey kepatuhan pajak bahwa "memasukkan faktor moral dan dinamika sosial pada model kepatuhan pajak merupakan area yang belum terjamah dalam penelitian".

Graetz and Wiede (1985) (dalam Simanjuntak dan Mukhlis, 2012) menyimpulkan bahwa tax morale juga adalah etika yang mengukur seberapa jauh tingkat komitmen Wajib Pajak atas kewajiban pertanggungjawaban warga negara mematuhi aturan pajak. Oleh karena itu, apabila faktor komitmen ini hilang, maka tingkat etikapun ternodai. Oleh karena itulah, menipisnya etika dapat dipersalahkan atau menurunnya tingkat kepatuhan pajak.

\subsection{Kepatuhan}

Kondisi perpajakan yang menuntut keikutsertaan aktif Wajib Pajak dalam menyelenggarakan perpajakannya membutuhkan kepatuhan Wajib Pajak yang tinggi, yaitu kepatuhan dalam pemenuhan kewajiban perpajakan yang sesuai dengan kebenarannya. Menurut Kamus Umum Bahasa Indonesia (1995), istilah Kepatuhan berarti tunduk atau patuh pada ajaran atau aturan.

\subsection{Penelitian Terdahulu}

Penelitian yang menjadi acuan utama dalam penyusunan usulan penelitian ini adalah penelitian yang dilakukan oleh Azmi dan Perumal (2008) dengan judul "The Impact of Tax Fairness Dimensions in an Asian Context: The Malaysian Perspective." Tujuan dari penelitian ini adalah untuk menyelidiki dampak dimensi keadilan pajak pada perilaku kepatuhan pajak di Malaysia yang kemudian akan dibandingkan dengan hasil penelitian yang dilakukan di Amerika Serikat untuk mempertimbangkan setiap kesamaan atau perbedaan perilaku kepatuhan pajak lintas budaya dan hasil analisis; faktor menunjukkan bahwa terdapat tiga dimensi keadilan pajak yang berpengaruh di Malaysia, yaitu keadilan umum (general fairness), struktur pajak (tax rate structure), dan kepentingan pribadi (self interest).

Penelitian yang dilakukan oleh Azmi dan Perumal (2008) merupakan penelitian yang mereplikasi penelitian Richardson (2006) dengan menggunakan Malaysia sebagai tempat penelitiannya. Berdasarkan hasil analisis faktor, Azmi dan Perumal (2008) menemukan bahwa hanya tiga dimensi keadilan pajak, yaitu General Fairness, Tax Structure, dan Self Interest yang memiliki hubungan positif signifikan terhadap perilaku kepatuhan pajak. Hal ini dikarenakan orang-orang Malaysia menganggap bahwa dimensi Exchange with Government bukanlah bagian yang terpisah dari dimensi General Fairness dan dimensi Tax Rate tidak terpisah dari dimensi Special Privileges for the Wealthy.

\subsection{Kerangka Teori dan Pengembangan Hipotesis}

Pemberlakuan pajak kepada Wajib Pajak pada prinsipnya harus memiliki dimensi keadilan bagi setiap Wajib Pajak. Menurut Jackson dan Milliron (1986), dalam Richardson (2006), dimensi keadilan pajak merupakan variabel nonekonomi kunci yang memengaruhi perilaku kepatuhan pajak. Christesen dalam Azmi dan Perumal (2008), mengungkapkan empat masalah utama yang menyebabkan perbedaan 
hasil dari penelitian-penelitian sebelumnya, yaitu keadilan pajak (1) merupakan masalah dimensional, (2) dapat didefinisikan pada tingkat individu maupun pada mayarakat luas, (3) keadilan terkait dengan kompleksitas, dan (4) kurangnya keadilan dapat menjadikan pertimbangan atau menyebabkan ketidakpatuhan. Selain keempat masalah tersebut, tidak dapat dihindari adanya pengaruh demografis yang mempengaruhi budaya masyarakat.

Azmi dan Perumal (2008) mengidentifikasi empat dimensi keadilan pajak yang memengaruhi perilaku kepatuhan pajak, yaitu: (1) Keadilan Umum (General Fairness). Dimensi ini terkait dengan keadilan menyeluruh atas sistem perpajakan dan distribusi pajak. (2) Timbal balik Pemerintah (Exchange with Government). Dimensi ini terkait dengan timbal balik yang secara tidak langsung diberikan pemerintah atas pajak yang dibayarkan oleh Wajib Pajak. (3) Kepentingan Pribadi (Self-Interest). Dimensi ini terkait dengan apakah jumlah pajak yang dibayarkan Wajib Pajak secara pribadi terlalu tinggi dan jika dibandingkan dengan Wajib Pajak lainnya. (4) Ketentuanketentuan khusus (Special Provisions). Dimensi ini terkait ketentuan-ketentuan khusus yang diberikan kepada Wajib Pajak tertentu, misalnya insentif pengurangan tarif untuk perusahaan go public.

Terkait dengan tax morale (moralitas pajak) dan kaitannya dengan kepatuhan pajak, penelitian Benno Torgler (2007) menunjukkan bahwa pembayar pajak lebih terdorong untuk patuh terhadap undang-undang jika pertukaran antara pajak yang dibayar dan kinerja pelayananpemerintah berimbang. Torgler juga menemukan korelasi positif antara relijiusitas dengan tingkat kepatuhan pajak. Selanjutnya Benno Torgler (2007) menjelasakan terkait dengan institusi, ditemukan fakta bahwa demokrasi langsung, tingkat kepercayaan pada pemerintah, sistem hukum dan peradilan. Salah satu ukuran rendahnya moralitas pajak adalah tingginya tingkat ekonomi informal (shadow economy).

Penelitian yang dilakukan sebelumnya oleh Parker et al (1995), dan Mustikasari (2007), menunjukkan bahwa tingkat moral individu secara signifikan berpengaruh terhadap kepatuhan pajak. Demikian pula penelitian yang dilakukan oleh Wenzel (2004), menyatakan bahwa individu yang memiliki norma individu yang kuat dalam kejujuran dan moral pajak lebih berperilaku patuh.

Berdasarkan dugaan tersebut, maka dikembangkanlah hipotesis penelitian berikut ini:
H1 : Untuk menguji apakah terdapat pengaruh secara parsial dari variabel dimensi keadilan pajak terhadap kepatuhan Wajib Pajak.

Penerapan keadilan akan lebih optimal, jika pengambil keputusan memberikan penjelasan berbentuk alasan dan pembenaran. Pada penjelasan berbentuk alasan, pengambil keputusan mengakui bahwa kegiatan yang dilakukan tidak menguntungkan serta meniadakan tanggung jawab organisasi dengan menyebutkan alasan yang disebabkan oleh beberapa faktor eksternal. Sementara pada penjelasan berbentuk pembenaran, pengambil keputusan menerima seluruh tanggung jawab, tetapi mengingkari bahwa kegiatan yang dilakukan tidak tepat, dengan maksud untuk memenuhi beberapa tujuan utama mereka sendiri. Penjelasan berbentuk pembenaran kemungkinan akan memberi pengaruh yang lebih tinggi kepada persepsi keadilan dibandingkan dengan penjelasan berbentuk alasan. Akhirnya, mereka menyimpulkan bahwa keadilan berpengaruh secara langsung maupun tidak langsung terhadap loyalitas melalui kepuasan pelanggan.

$\mathrm{H} 2$ : Untuk menguji apakah terdapat pengaruh secara parsial dari variabel tax morale kepatuhan Wajib Pajak.

Studi yang dilakukan oleh Riahi-Belkaoiu (2004) menunjukkan bahwa apabila negara mampu menjamin kebebasan melakukan aktivitas ekonomi yang menjunjung persaingan bebas kepada warganya maka moral untuk membayar pajak akan semakin meningkat. Implikasi membaiknya moral masyarakat akan berdampak pada peningkatan kepatuhan untuk membayar pajak.Penelitian yang dilakukan sebelumnya oleh Parker et al (1995), dan Mustikasari (2007), menunjukkan bahwa tingkat moral individu secara signifikan berpengaruh terhadap kepatuh-an pajak. Demikian pula penelitian yang dilaku-kan oleh Wenzel (2004), menyatakan bahwa individu yang memiliki norma individu yang kuat dalam kejujuran dan moral pajak lebih berperilaku patuh.

H3 : Untuk menguji apakah terdapat pengaruh secara simultan dari variabel dimensi keadilan pajak dan tax morale terhadap kepatuhan Wajib Pajak.

Secara relasional, tingkat kepatuhan pajak juga dipengaruhi perilaku sesama pembayar pajak. Jika penghindaran pajak ditoleransi, maka cenderung mendorong ketidakpatuhan pembayar pajak. Di sisi lain ditunjukkan bahwa apabila administrasi perpajakan mencoba untuk bersikap jujur, informatif, tanggap dalam melayani, bertindak sebagai institusi pelayan, dan memperlakukan pembayar pajak sebagai mitra pembayar pajak cenderung ingin bekerjasama dengan otoritas. 


\section{Metode Penelitian}

\subsection{Data dan Sampel}

Populasi dari penelitian ini adalah Wajib Pajak yang terdaftar di Kantor Pelayanan Pajak Pratama Kota Bandung. Wajib Pajak terdaftar ditandai dengan kepemilikan Nomor Pokok Wajib Pajak (NPWP). Wajib Pajak di Indonesia terbagi menjadi dua jenis, yaitu Wajib Pajak Orang Pribadi (WP OP) dan Wajib Pajak Badan (WP Badan).

Untuk mendapatkan sampel yang representatif, maka dalampenelitian inidigunakan teknik pengambilan sampeldengan cara proportional random sampling. Populasi sasaran dalam penelitian ini adalah Wajib PajakBadan yang terdaftar di KPP Pratama Kota Bandung tahun 2011 yang terbagi kedalam 5 wilayah yaitu KPP Pratama Bandung Bojonagara, KPP Pratama Bandung Cibeunying, KPP Pratama Bandung Cicadas, KPP Pratama Bandung Karees dan KPP Pratama Bandung Tegalega yang berjumlah 22.377 Wajib Pajak Badan.

Sampel diambil 100 sampel yang ditentukan berdasarkan teknik penentuan ukuran sampel yang menggunakan rumus sebagai berikut(Bungin, 2009):

$n=\frac{N}{N d^{2}+1}$

Dari jumlah populasi tersebut dengan tingkat kelonggaran ketidaktelitiansebesar 10\%, maka dengan menggunakan rumus diatas diperoleh sampel sebesar:

$n=\frac{22.377}{1+22.377(0,1)^{2}}=99,98 \sim 100$

Karena jumlah sub populasinya tidak sama antara setiap KPP, maka penentuan jumlah sampel tiaptiap sub populasinya menggunakan prosedur proportional stratified random sampling, dengan cara mengambil sampel secara acak dengan jumlah proporsional untuk masing-masing KPP.

Tabel 3.1 Populasi dan Sampel

\begin{tabular}{|c|l|c|c|}
\hline $\mathbf{N}$ & Nama KPP & $\begin{array}{l}\text { Populasi (WP } \\
\text { oadan terdaftar) }\end{array}$ & Sampel \\
\hline 1 & $\begin{array}{l}\text { KPP Pratama } \\
\text { Bandung Tegallega }\end{array}$ & 3.014 & 15 \\
\hline 2 & $\begin{array}{l}\text { KPP Pratama } \\
\text { Bandung } \\
\text { Cibeunying }\end{array}$ & 5.073 & 23 \\
\hline 3 & $\begin{array}{l}\text { KPP Pratama } \\
\text { Bandung Karees }\end{array}$ & 5.392 & 24 \\
\hline 4 & $\begin{array}{l}\text { KPP Pratama } \\
\text { Bandung } \\
\text { Bojonagara }\end{array}$ & 3.521 & 15 \\
\hline 5 & $\begin{array}{l}\text { KPP Pratama } \\
\text { Bandung Cicadas }\end{array}$ & 5.377 & 23 \\
\hline & Jumlah & 22.377 & 100 \\
\hline
\end{tabular}

Sumber : Data diolah dari Kanwil DJP Jabar I

\subsection{Metode Penelitian yang digunakan}

Secara umum tujuan penelitian ini adalah untuk menguji hipotesis. Berdasarkan tujuan penelitian tersebut, maka penelitian ini termasuk jenis penelitian penjelasan (explanatory research), yang akan menjelaskan hubungan kausal antara variabel bebas dan variabel terikat melalui pengujian hipotesis. Dalam penelitian ini, peneliti mengumpulkan data primer dengan cara kuesioner. Kuesioner merupakan pengumpulan data yang dilakukan dengan cara memberi seperangkat pertanyaan atau pernyataan tertulis kepada responden untuk dijawabnya (Sugiyono, 2012). Kuesioner diberikan kepada Wajib Pajak Badan yang dijadikan sampel.

Teknik yang akan dipergunakan sebagai alat analisis (tool analysis) dalam penelitian ini adalah metode Structural Equation Modeling (SEM) berbasis varian atau komponen, yaitu PLS (Partial Least Square). Sebelumnya data yang diperoleh dari para responden, perlu diuji reliabilitas dan validitasnya terlebih dahulu.Hal ini dilakukan untuk menghindari keraguan terhadap alat ukur.

\section{Hasil dan Pembahasan}

Berdasarkan hasil pengujian secara statistik yang dihasilkan, dapat disimpulkan bahwa dimensi keadilan pajak dan tax morale yang berpengaruh positif dan signifikan pada kepatuhan pajak wajib pajak badan. Hal ini ditunjukkan dengan hasil uji terhadap koefesien parameter antara dimensi keadilan pajak terhadap kepatuhan menunjukkan ada pengaruh positif 0,401394 , sedangkan nilai $T$ statistik sebesar 3,665772 dan signifikan pada ㅍ $5 \%$. Nilai tersebut berada lebih dari $(1,96)$, sedangkan hasil uji terhadap koefisien parameter antara tax morale terhadap kepatuhan menunjukkan ada pengaruh positif 0,3888658 , sedangkan nilai $T$ statistik sebesar 2,836782 dan signifikan pada ㅍ $5 \%$. Nilai tersebut berada lebih dari $(1,96)$.

\subsection{Pengaruh Dimensi Keadilan Pajak Terhadap Tingkat Kepatuhan Wajib Pajak Badan yang Terdaftar di KPP Pratama Kota Bandung}

Berdasarkan hasil pengujian secara statistik yang dihasilkan dan pengujian dengan model struktural outer model (analisis faktor dan analisis reliabilitas) teridentifikasi lima dimensi keadilan pajak, yaitu keadilan umum (general fariness), timbal balik pemerintah (exchange with government), kepentingan pribadi (self interest), ketentuanketentuan khusus (special provisions), dan struktur tarif pajak (tax rate structure). Hasilnya menunjukkan bahwa setelah dipengaruhi hal tersebut di atas, maka secara statistik berpengaruh signifikan terhadap 
tingkat kepatuhan Wajib Pajak Badan yang terdaftar di KPP Pratama Kota Bandung.Hal ini menunjukkan dimana dari dimensi keadilan pajak memiliki signifikansi (t statistik) lebih dari t tabel $(>1,96)$.

1. Keadilan Umum (General Fairness/KP1) Hasil pengujian inner model menunjukkan bahwa keadilan umum secara statistik berpengaruh signifikan terhadap kepatuhan Wajib Pajak Badan. Nilai inner weight yang diperoleh 0,356 signifikan pada ㅍ 5\%. Wajib Pajak Badan menganggap bahwa sistem pajak penghasilan di Indonesia diatur secara adil untuk rata-rata Wajib Pajak dan pembebanan pajak penghasilan didistribusikan secara adil kepada setiap Wajib Pajak secara umum telah adil, namun rasa keadilan ini berpengaruh terhadap kepatuhan pajaknya. Wajib Pajak Badan lebih berorientasi pada aturan yang berlaku dan sanksi yang mungkin diterima dalam membayar pajak dibandingkan dengan keadilan yang mereka terima. Hasil pengujian ini tidak berbeda dengan penelitian yang dilakukan Azmi dan Perumal (2008) maupun Richardson (2006) yang menyatakan bahwa keadilan umum berpengaruh signifikan terhadap kepatuhan pajak.

2. Timbal Balik Pemerintah (Exchange with Government/KP2)

Hasil pengujian inner model menunjukkan bahwa timbal balik pemerintah secara statistik berpengaruh signifikan terhadap kepatuhan Wajib Pajak Badan. Nilai inner weight yang diperoleh 0,273 signifikan pada 땨 5\%. Wajib Pajak Badan menganggap bahwa timbal balik yang diberikan pemerintah sebagai kompensasi pembayaran pajak merupakan timbal balik yang diberikan secara tidak langsung sehingga Wajib Pajak Badan tidak merasakan manfaatnya secara menyeluruh dalam hal ini dapat mempengaruhi dalam kepatuhan pajaknya. Hasil pengujian ini tidak berbeda dengan penelitian yang dilakukan Azmi dan Perumal (2008) maupun Richardson (2006) yang menyatakan bahwa timbal balik pemerintah berpengaruh signifikan terhadap kepatuhan pajak.

3. Kepentingan Pribadi (Self $\square$ Wterest/KP3) Hasil pengujian inner model menunjukkan bahwa kepentingan pribadi secara statistik berpengaruh signifikan terhadap kepatuhan Wajib Pajak Badan. Nilai inner weight yang diperoleh 0,194 signifikan pada ㅍ 5\%. Wajib Pajak Badan menganggap bahwa kepentingan pribadi Wajib Pajak Badan tidak dapat menjadi tolok ukur perilaku kepatuhan pajak. Hal ini dikarenakan meskipun pajak yang mereka bayar lebih tinggi maupun tidak, Wajib Pajak Badan akan tetap membayarkan pajak penghasilannya. Peraturan-peraturan pajak yang mengikat lebih menjadi pertimbangan dalam membayarkan pajak. Kemungkinan sanksi yang mereka terima akan menjadi perhatian lebih dibandingkan hanya mempertimbangkan apakah kepentingan mereka dapat terpenuhi dengan membayar pajak penghasilan. Hasil pengujian ini tidak berbeda dengan penelitian yang dilakukan Azmi dan Perumal (2008) yang hasilnya menunjukkan bahwa terdapat tiga dimensi keadilan pajak yang berpengaruh di Malaysia, yaitu keadilan umum (general fairness), struktur pajak (tax rate structure), dan kepentingan pribadi (self interest) sedangkan Richardson (2006) yang hasilnya menunjukkan bahwa setelah dipengaruhi oleh variabel demografi, menunjukkan bahwa dimensi keadilan umum (general fairness), pembebanan pajak penghasilan pada penerima penghasilan menengah (middle income earners tax share/burden), timbal balik pemerintah (exchange with government) secara statistik berpengaruh signifikan terhadap perilaku kepatuhan pajak.

4. Ketentuan-Ketentuan Khusus (Special Provisions/ KP4)

Hasil pengujian inner model menunjukkan bahwa ketentuan-ketentuan khusus secara statistik berpengaruh signifikan terhadap kepatuhan Wajib Pajak Badan. Nilai inner weight yang diperoleh 0,256 signifikan pada 먀 5\%. Wajib Pajak Badan menganggap bahwa adanya ketentuan-ketentuan khusus yang meringankan Wajib Pajak Badan dalam membayarkan pajak ini berpengaruh terhadap kepatuhan pajaknya. Ketentuan-ketentuan khusus yang dapat mengurangi pajak yang dibayarkan dirasakan kurang adil oleh Wajib Pajak Badan karena telah memberikan keringanan pada seluruh lapisan penghasilan, baik yang berpenghasilan kecil maupun berpenghasilan besar. Keputusan Wajib Pajak Badan untuk membayarkan pajaknya secara tepat waktu bukan karena perasaan adil karena adanya keringanan-keringanan tertentu tetapi lebih pada rasa keterikatan mereka pada peraturan yang berlaku. Hasil pengujian ini tidak berbeda dengan penelitian yang dilakukan Azmi dan Perumal (2008) maupun Richardson (2006) yang menyatakan bahwa ketentuan-ketentuan khusus berpengaruh signifikan terhadap kepatuhan pajak.

5. Struktur Tarif Pajak (Tax Rate Structure/KP5) Hasil pengujian inner model menunjukkan bahwa struktur tarif pajak secara statistik berpengaruh signifikan terhadap kepatuhan Wajib Pajak Badan. 
Nilai inner weight yang diperoleh 0,289 signifikan pada 땨 5\%. Wajib Pajak Badan menganggap bahwa perubahan struktur tarif pajak pajak yang berlaku dari tarif proporsional mejadi tarif flat tidak dapat menjadi alasan Wajib Pajak Badan untuk patuh atau tidak dalam membayar pajak, baik tarif pajak dikenakan secara proporsional maupun flat Wajib Pajak Badan akan tetap membayar pajaknya. Wajib Pajak Badan lebih berorientasi pada aturan yang berlaku dan sanksi yang mungkin diterima dalam membayar pajak dibandingkan dengan struktur tarif pajak yang sudah ditetapkan harus di terima. Hasil pengujian ini tidak berbeda dengan penelitian yang dilakukan Azmi dan Perumal (2008) maupun Richardson (2006) yang menyatakan bahwa struktur tarif pajak berpengaruh signifikan terhadap kepatuhan pajak.

Dari penjelasan di atas bahwa variabeldimensi keadilan pajak berpengaruh positif terhadap kepatuhan. Hasil ujinya terhadap koefisien parameter antara dimensi keadilan pajak terhadap kepatuhan menunjukkan ada pengaruh positif 0,401394 , sedangkan nilai $T$ statistik sebesar 3,665772 dan signifikan pada 땨 5\%. Nilai tersebut berada lebih dari $(1,96)$.

\subsection{Pengaruh Tax Morale Terhadap Tingkat Kepatuhan Wajib Pajak Badan yang Terdaftar di KPP Pratama Kota Bandung}

Berdasarkan hasil pengujian secara statistik yang dihasilkan dan pengujian dengan model struktural outer model (analisis faktor dan analisis reliabilitas) teridentifikasi tiga dimensi tax morale, yaitu melanggar etika, perasaan bersalah, dan prinsip hidup. Hasilnya menunjukkan bahwa setelah dipengaruhi hal tersebut di atas, maka secara statistik berpengaruh signifikan terhadap tingkat kepatuhan Wajib Pajak Badan yang terdaftar di KPP Pratama Kota Bandung. Hal ini menunjukkan dimana dari tax morale memiliki signifikansi (t statistik) lebih dari t tabel $(>1,96)$.

1. Melanggar etika (TM1)

Hasil pengujian inner model menunjukkan bahwa melanggar etika secara statistik berpengaruh signifikan terhadap kepatuhan Wajib Pajak Badan. Nilai inner weight yang diperoleh 0,760 signifikan pada 냐 5\%. Wajib Pajak Badan menganggap bahwa melanggar etika ini dapat berpengaruh terhadap kepatuhan pajaknya. Variabel tax morale dapat menentukan sikap wajib pajak dalam kepatuhan pajaknya yang sangat dipengaruhi oleh tingkat kepercayaan kepada sistem hukum dan peradilan serta institusi dari aparat pajak. Hasil pengujian ini tidak berbeda dengan penelitian yang dilakukan Mustikasari (2007) yang hasilnya bahwa kewajiban moral berpengaruh positif dan signifikan terhadap niat untuk tidak patuh individu terhadap pajak sedangkan Torgler, Benno dan F. Schenaider (2007) yang hasilnya ada suatu pengaruh yang signifikan antara variabel moral wajib pajak dan pembayaran pajak serta kepatuhan pajak.

\section{Perasaan Bersalah (TM2)}

Hasil pengujian inner model menunjukkan bahwa perasaan bersalah secara statistik berpengaruh signifikan terhadap kepatuhan Wajib Pajak Badan. Nilai inner weight yang diperoleh 0,806 signifikan pada 먀 5\%. Wajib Pajak Badan menganggap bahwa perasaan bersalah ini dapat berpengaruh terhadap kepatuhan pajaknya, karena sangat tergantung dari kekuatan kepribadian dan perilaku wajib pajak dalam melaporkan pajaknya artinya perasaan bersalah sangat didasari dari kepribadian dan perilaku yang akan memberikan implikasi terhadap kepatuhannya dalam melaporkan pajaknya. Hasil pengujian ini tidak berbeda dengan penelitian yang dilakukan Mustikasari (2007) yang hasilnya bahwa perasaan bersalah berpengaruh positif dan signifikan terhadap niat untuk tidak patuh individu terhadap pajak.

3. Prinsip Hidup (TM3)

Hasil pengujian inner model menunjukkan bahwa prinsip hidup secara statistik berpengaruh signifikan terhadap kepatuhan Wajib Pajak Badan. Nilai inner weight yang diperoleh 0,805 signifikan pada 몌 $5 \%$. Wajib Pajak Badan menganggap bahwa prinsip ini dapat berpengaruh terhadap kepatuhan pajaknya, karena pada umumnya Wajib Pajak dapat bertindak sesuai dengan niat atau tendensinya untuk patuh atau tidak patuh dalam melaksanakan kewajiban perpajakannya. Hasil pengujian ini tidak berbeda dengan penelitian yang dilakukan Mustikasari (2007) yang hasilnya bahwa prinsip hidup berpengaruh positif dan signifikan terhadap niat untuk tidak patuh individu terhadap pajak.

Dari penjelasan di atas bahwa tax morale berpengaruh positif terhadap kepatuhan. Hasil ujinya terhadap koefisien parameter antara tax morale terhadap kepatuhan menunjukkan ada pengaruh positif 0,3888658 , sedangkan nilai $T$ statistik sebesar 2,836782 dan signifikan pada ㅍ $5 \%$. Nilai tersebut berada lebih dari $(1,96)$.

\section{Simpulan}

Berdasarkan analisis studi dan pembahasan yang telah dibahas pada bab-bab sebelumnya, dapat disusun suatu kesimpulan sebagai berikut : 
1. Dimensi keadilan pajak berpengaruh signifikan pada kepatuhan Wajib Pajak Badan di KPP Pratama Kota Bandung, berdasarkan hasil analisis faktor analisis reabilitas, teridentifikasi lima dimensi keadilan pajak menunjukkan bahwa keadilan umum (general fairness), timbal balik pemerintah (exchange with government), kepentingan pribadi (self interest), ketentuan-ketentuan khusus (special provisons), dan struktur tarif pajak (tax rate structure) ternyata berpengaruh terhadap tax compliance Wajib Pajak Badan di KPP Pratama Kota Bandung. Hal ini dikarenakan Wajib Pajak Badan di KPP Pratama Kota Bandung menganggap dimensi keadilan pajak belum memenuhi harapan Wajib Pajak Badan yang terdaftar di KPP Pratama Kota Bandung, dengan kata lain secara umum Wajib Pajak Badan dapat merasakan bagaimana sistem pajak penghasilan dan pembebanan pajak penghasilan didistribusikan terhadap Wajib Pajak Badan yang diberlakukan, begitu pula timbal balik pemerintah yang belum maksimal, adanya kepentingan pribadi dan ketentuanketentuan khusus yang memperlakukan Wajib Pajak yang memiliki kondisi ekonomi atau penghasilan berbeda dengan cara yang berbeda pula, serta penerapan tarif pajak yang sama (flat) terhadap penghasilan Wajib Pajak Badan, sehingga dapat dikatakan dimensi keadilan pajak yang dirasakan oleh Wajib Pajak Badan di KPP Pratama Kota Bandung belum dirasakan maksimal sehingga dapat memengaruhi tingkat kepatuhan pajaknya.

2. Variabel tax morale dapat menentukan sikap wajib pajak dalam kepatuhan pajaknya bahwa melanggar etika ini dapat berpengaruh terhadap kepatuhan pajaknya yang sangat dipengaruhi oleh tingkat kepercayaan kepada sistem hukum dan peradilan serta institusi dari aparat pajak, begitupula bahwa perasaan bersalah ini dapat berpengaruh terhadap kepatuhan pajaknya artinya perasaan bersalah sangat didasari dari kepribadian dan perilaku yang akan memberikan implikasi terhadap kepatuhannya dalam melaporkan pajaknya sedangkan prinsip hidup ini dapat berpengaruh terhadap kepatuhan pajaknya, karena pada umumnya Wajib Pajak dapat bertindak sesuai dengan niat atau tendensinya untuk patuh atau tidak patuh dalam melaksanakan kewajiban perpajakannya.
3. Secara keseluruhan variabel-variabel dimensi keadilan pajak dan tax morale berpengaruh terhadap tingkat kepatuhan pajak.

\section{Daftar Pustaka}

Albari. 2008. Pengaruh Keadilan Terhadap Kepuasan dan Kepatuhan Wajib Pajak. Jurnal UNISIA. Vol. XXXI No. 69.

Alm, and Torgler. 2005. Culture Differences and Tax Morale in the United States and in Europe, Journal of Public and Public Choice 19: 143 168.

Azmi, Anna A. Che and Kamala A. Perumal. 2008. Tax Fairness Dimensions in an Asian Context: The Malaysian Perspective, International review of Business Research Papers. Vol. 4 No. 5 p11 - 19. Diakses Bulan Agustus 2012.

Bruno S. Frey \& Benno, Torgler. 2007. Tax Morale Conditional Cooperation. Journal of Comparative Economics No. 35, p 136 - 159.

Carolina, Verani. 2011. Pengaruh Tax Knowledge dan Persepsi Tax Fairness Terhadap Tax Compliance Wajib Pajak Badan yang Terdaftar di KPP Madya Bandung. Tesis: Universitas Kristen Maranatha.

Frey. 1997. The Role of Deterrence and Tax Morale in Taxation in the European Union. Jelle Zijlstra Lecture, Netherlands Institution for Advance Study in the Hummanities and Social Sciences (NIAS).

Frey and Feld. 2002. The Role of Deterrence and Morale in Taxation: An Empirical Analysis CESifo Working Paper No. 760.

Gerbing, M.D. 1988. An Empirical Study of Taxpayer Perceptions of Fairness. Unpublished PhD Thesis, University of Texas.

Ghozali, Imam. 2006. Analisis Multivariate Dengan Program SPSS. Semarang: Badan Penerbit Universitas Diponegoro.

Ghozali, Imam. 2008. Structural Equation Modeling: Metode Alternatif dengan Partial Least Square. Semarang: Badan Penerbit Universitas Diponegoro.

Hidayat, Widi \& Nugroho, Adhi Argo. 2010. Studi Empiris Theory of Planned Behavior dan Pengaruh Kewajiban Moral pada Perilaku Ketidakpatuhan Pajak Wajib Pajak Orang Pribadi. Jurnal Akuntansi dan Keuangan. Vol. 12 No. 2, p $82-93$. 
Kamus Besar Bahasa Indonesia. www.pusatbahasa.diknas.go.id diakses tanggal 3 September 2012.

Mardiasmo. 2011. Perpajakan Edisi Revisi 2011. Yogyakarta: Penerbit Andi.

Murphy, Kristin. 2003. An Examination of Taxpayers attitutudes Towards The Australian Tax System: Findings From A Survey of Tax Scheme Investor, Tax Forum 18(2): p209 - 242.

Mustikasari, Elia. 2007. Kajian Empiris tentang Kepatuhan Wajib Pajak di Perusahaan Pengolahan di Surabaya. Seminar Nasional Akuntansi X. IAI - KAPd.

Ompusunggu, Parulian Arles \& Trisnawati Estralita. 2010. Pengaruh Umur, Pendapatan, Moral Terhadap Pembayaran Pajak dan Tax Evasion. Jurnal Akuntabilitas Vol. 10 No. 1

Peraturan Menteri Keuangan Republik Indonesia Nomor 192/PMK.03/2007 tentang Tata Cara Penetapan Wajib Pajak dengan Kriteria Tertentu Dalam Rangka Pengembalian Pendahuluan Kelebihan Pembayaran Pajak.

Resmi, Siti. 2011. Perpajakan: Teori dan Kasus. Jakarta: Salemba Empat.

Richardson, Grant. 2006. The Impact of Tax Fairness Dimension on Tax Compliance Behavior in an Asian Jurisdiction: The Case of Hong Kong. International Tax Journal.

Richardson, Grant. 2006. Determinants of Tax Evasion: A Cross Country Investigation. Journal of International Accounting, Auditing and Taxation Number 15, p $150-$ 169.

Richardson, M., and Sawyer, A.J. 2001. A Taxonomy of The Tax Compliance Literature: Further Findings, Problems and Prospects. Australian Tax Forum, Vol. 16, pp $137-320$.

Santoso, Singgih. 2010. Mastering SPSS 18. Jakarta: Elex Media Komputindo.

Sugiyono. 2012. Metode Penelitian Pendidikan: Pendekatan Kuantitatif, Kualitatif, dan $R$ \& D. Bandung: Alfabeta.

Simanjuntak, Timbul Hamonangan. 2008. Analisis Kepatuhan Pajak dan Dampaknya Pada Dana Perimbangan Keuangan dan Pengeluaran Pemerintah Daerah serta
Kesejahteraan Masyarakat Kabupaten/Kota di Provinsi Jawa Timur. Disertasi. Surabaya.

Simanjuntak, Timbul Hamonangan \& Mukhlis, Imam. 2012. Dimensi Ekonomi Perpajakan Dalam Pembangunan Ekonomi. Jakarta: Penerbit Raih Asa Sukses.

Torgler, Benno and F. Schenaider. 2007. The Impact of Tax Morale and Institutional Quality on the Shadow Economy. IZA DP No. 2541.

Torgler, Benno, Markus Schaffner and Alison Macinttyre. 2007. Tax Evasion, Tax Morale and Institutions. Georgia State Univeristy in Alabama Working Paper.

Undang-Undang Republik Indonesia Nomor 28 Tahun 2007 Tentang Ketentuan Umum dan Tata Cara Perpajakan.

Undang-Undang Republik Indonesia Nomor 36 Tahun 2008 Tentang Pajak Penghasilan.

Undang-Undang Republik Indonesia Nomor 16 Tahun 2009 Tentang Tentang Ketentuan Umum dan Tata Cara Perpajakan.

http://www.pajak.go.id, Berita Pajak, 8 Mei 2012, diakses pada bulan April 2013.

http://www.indodigest.com, Berita Pajak, Wiyoso Hadi, Pegawai DJP, 8 Mei 2012, diakses pada bulan April 2013.

http:///bisnisjabar.co.id, kabar ekonomi, 25 Februari 2012, diakses pada bulan April 2013. 